DOI: 10.46340/eujem.2020.6.4.7

\author{
Andriy Hrymalyuk, PhD in Economics \\ ORCID ID: https://orcid.org/0000-0002-8323-919, \\ Pavlo Nesenenko, PhD in Economics \\ ORCID ID: https://orcid.org/0000-0001-6399-3511 \\ Tetyana Sukhova \\ ORCID ID: https://orcid.org/0000-0001-9208-8828 \\ Odesa National Economic University, Ukraine

\section{THE TRANSFORMATION \\ OF HUMAN ACTIVITYIN THE MODERN ECONOMY: METHODOLOGICAL AND THEORETICAL BASES OF ANALYSIS}

The article shows that the synthesis of the concept of economic choice from various alternative options and, on the other hand, a historical approach to the analysis of creative activity, allows us to establish a methodological connection between neoclassical microeconomics and political economy, which contributes to the integration of economic theory as a single scientific discipline. Moreover, the key problem of such a methodological synthesis is the question of creating new alternative opportunities for economic choice. This concept opens the way for the categorical inclusion of the specific activities of the creative class in the subject of economic theory. In the future, such an analysis of creative activity is capable of laying the methodological foundations of the study of the creative transformation of human activity, opening up opportunities for the development of economic theory.

Keywords: creative activity, alternative choice, creative class, elements of creativity, subject of economic theory, methodological synthesis.

Formulation of the problem. The trends in the creative transformation of human activity in modern conditions have been most vividly embodied in enhancing the economic role of the creative class. According to his "discoverer" Richard Florida, with the formation of a "creative class" that unites more than $30 \%$ of the work force in the USA, "deep and significant changes are connected in our habits and working methods, values and aspirations, as well as in the very structure of our everyday life" ${ }^{1}$. As a large-scale study conducted by R. Florida together with I. Tinagli shows, similar processes occur in Europe ${ }^{2}$. In general, the development of the elements of creativity in the content of human activity appears as the most important historical trend that defines the features of modern economic development ${ }^{3,4,5}$. The importance of these extremely complex issues determines the particular relevance of the search for the methodological foundations of the analysis of the creative transformation of human activity in the modern knowledge economy.

Analysis of recent research and publications. In modern economic literature, creative activity is considered as a process of direct, inalienable cooperation, dialogue, free from the economic necessity of subject-subject communication ${ }^{6,7}$. A. A. Gritsenko, A. V. Buzgalin,

\footnotetext{
${ }^{1}$ Florida, R. (2002). The Rise of the Creative Class. And How It's transforming Work, Leisure, Community and Everyday Life. New York: Basic Books.

${ }^{2}$ Florida, R., Tinagli, I. (2004) Europe in the Creative Age. Pittsburgh: Carnegie Mellon Software Industry Center. London Demos. February, 17-21.

${ }^{3}$ Florida, R. (2004). Creative Class War. Washington Monthly. February, 9.

4 Лэндри, Ч. (2006). Креативный город. Москва: Классика XXI, 57-69.

${ }^{5}$ Хокинс, Дж. (2006). Креативная экономика. Москва: Классика XXI, 112-125.

${ }^{6}$ Хокинс, Дж. (2006). Креативная экономика. Москва: Классика XXI, 124.

${ }^{7}$ Florida, R. (2004). Creative Class War. Washington Monthly. February, 7-18.

${ }^{8}$ Бузгалин, А.В., Колганов, А.И. (2019). Предель капитала: методология и онтология. Москва: Культурная революция.
} 
A. Gorz ${ }^{1,2,3}$, A. I. Kolganov, V. L. Inozemtsev, V. M. Mezhuev, V. G. Arslanov, S. S. Dzarasov and others proceed from the distinction between the two main forms directly social communication, immanent to two types of cooperation of labor, one of which is immanent to joint work, and the other is immanent to creativity, considered as universal labor ${ }^{4,5}$. At the same time, it is assumed that, unlike labor cooperation, universal, immanent to creativity, cooperation can be intertemporal in nature: it can cover the activities of not only contemporaries, but also the activities of predecessors ${ }^{6,7}$.

This is a special kind of cooperation, not limited by time and space: each scientist, regardless of the scale and significance of his personal contribution to universal labor, acts as a "dwarf standing on the shoulders of giants" in the sense that he relies on the universal work of his predecessors. Universal labor is regarded as the highest stage of development of social labor itself ${ }^{8,9}$. In general, creative transformation is seen as the process of cardinal change in the content of human activity beginning in today's highly developed countries towards the development of the elements of creativity in the content of labor and, on this basis, the gradual transformation of labor into creative activity ${ }^{10,11}$.

However, such development of categorical problems of the theory of the "creative class" and creative activity further divides political economy from the neoclassical theory, which remains the "mainstream" ("mainstream") of modern economic thought. This is largely due to the fact that the approach from the point of view of alternative possibilities of individual choice, prevailing in neoclassical microeconomics, is practically not applied to the solution of these theoretical issues. This circumstance interferes with the establishment of scientific links between political economy and neoclassical microeconomics and their integration into a single economic theory. Therefore, the aim of the article is to analyze the problem of creative activity from the perspective of alternative possibilities of individual choice, which allows establishing a methodological connection between political economy and neoclassical theory that would contribute to the development of integral economic theory as a single science.

Statement of the main material. Political economy cannot afford to go past the problems of the creative transformation of human activity, as the neoclassical theory actually does. Neoclassicism is not interested in where the alternative possibilities of an individual choice of economic entities come from. Taking this issue beyond the scope of its subject matter, modern microeconomics thereby actually transfers it into the jurisdiction of political economy, which is called upon to consider not only the use of alternative opportunities, but also their creation, due to the very nature of its subject.

This distinction of the subject of analysis proceeds from the actual difference in economic and creative activity. Economic activity includes two stages: 1) the choice of a certain option of activity from known alternatives; 2) the implementation of this alternative option in the process of objectification of activity as a result of it, that is, in the process of labor. As you know, political economy focuses on labor, focusing on the second stage of economic activity. On the other hand, neoclassical microeconomics, on the contrary, focuses on the first stage of economic activity, on the problem of choice.

However, this shift of attention from labor to choice is clearly not enough for an adequate analysis of the modern economy. The fact is that in this case, economic theory virtually excludes from its subject creative activity that can create new alternative choices. As a result, all attention is unilaterally fixed on the analysis of choice, and not on the creation of new opportunities for it, which forms the starting point of complex

\footnotetext{
${ }^{1}$ Горц, А. (2018). Нематериальное: знание, стоимость и капитал. К критике экономики знаний. Москва: ГУ-ВШЭ.

${ }^{2}$ Пусенкова, И.В. (2001). Методология анализа развития от экономики к интеллекту. Одесса: Астропринт. ${ }^{3}$ Florida, R. (2002). The Rise of the Creative Class. And How It's transforming Work, Leisure, Community and Everyday Life. New York: Basic Books, 27-29.

${ }^{4}$ Иноземцев В. Л. (1998). За пределами экономического общества. Москва: Наука, 127.

${ }_{5}^{5}$ Бузгалин, А.В., Колганов, А.И. (2019). Предель капитала: методология и онтология. Москва: Культурная революция, 215-223.

${ }_{6}^{6}$ Бузгалин, А.В., Колганов, А.И. (2017). Глобальньй капитал. Москва: Альтернативы, том 2, 312.

${ }^{7}$ Гриценко А.А. (2018). Развитие форм обмена, стоимости и денег. Киев: Основа, 183.

${ }^{8}$ Гриценко А. А. (2018). Совместно-разделенный труд как исходная категория политической экономии и её предмет. Вопросы политической экономии, 3 (18), 7-8.

${ }_{9}^{9}$ Межуев В. М. (2017). Маркс против марксизма. Москва: Логос, 135.

${ }^{10}$ Пусенкова, И.В. (2001). Методология анализа развития от экономики к интеллекту. Одесса: Астропринт, 78-79.

${ }^{11}$ Горц, А. (2018). Нематериальное: знание, стоимость и капитал. К критике экономики знаний. Москва: ГУ-ВШЭ, 112.
} 
activity, characteristic of the modern economy. In order to categorically express the features of a modern developed economy, it is necessary to shift the emphasis not from labor to choice, but from choice - to create new options for him and, therefore, from economic activity to creative.

In the economic activity of the classic individual producer ("simple commodity producer"), entrepreneurial choice and labor impact on the subject of labor are combined in one person. Moreover, this activity itself is usually actually separated from creativity, creating new alternative options for action. As a result of this social division of activities, activities separated from creativity are routine. The development of small-scale production is slow. It is not surprising, therefore, that small-scale production was in many cases incapable of confronting large-scale capitalist production, which presupposes entrepreneurship separated from direct labor and taking on the main problems of economic choice.

Capitalist enterprise means the relative separation of choice from labor. The entrepreneur concentrates on the functions of economic choice, the worker mainly on direct action acting as labor. In classical capitalist production, choice and labor are separated. The choice becomes the prerogative of the entrepreneur, and labor is assigned to the wage worker.

This new, specifically capitalist social division of activity into separate and opposing labor actions and entrepreneurial choices has received a peculiar expression in economic thought. On the one hand, the political economy based on the labor theory of value focuses on labor as an action directed directly at a material object. At the same time, subjective economic choice is being relegated to the background. On the other hand, Austrian and neoclassical schools emerged, focusing on the problem of economic choice and considering labor action only as one of the production resources or factors of production.

Modern economic theory places a special objectivity between the material world and the world of "praxeological reality" - alternative possibilities of human activity. "The praxeological reality is not the physical world," L. Mises emphasizes, "but a person's conscious reaction to this state of this world. Economic theory is not the science of objects and tangible material objects; it is a science about people, their intentions and actions. Goods, goods, wealth, and all other concepts of behavior are not elements of nature; they are elements of human intentions and behavior. Those who want to study them need not look at the outside world; he must look for them in the intentions of acting people ${ }^{1}$.

Mises praxeology does not seek to deny the objective existence of the material world; it is generally methodologically indifferent to the objectivity of its existence. She is interested in completely different, ideal objects of human activity - alternative opportunities from which the economic agent makes his choice, and not the materiality of those things with which these alternative opportunities are connected. Owing to this interest, not in material, but primarily in ideal objects of human activity or activity phenomena (by analogy with the Husserl understanding of the phenomenon as an intentional object), Austrian praxeology, in contrast to the activity approach characteristic of political economy, acts as a kind of phenomenology of human activity.

It is hardly accidental that in parallel with the penetration into the economic theory of the "Austrian" concept of alternative costs, considered as the costs of lost alternative possibilities, the concept of intentional objects developed by E. Husserl entered into modern thinking. In Husserl, intentional objects appear as images of material things, on which the consciousness of the knowing subject is directed ${ }^{2}$. If we assume that the subject is not contemplative, but acting, then it arises completely a new category of intentional objects intentional objects of choice, which are alternative possibilities of action. The identification of this special, "activity" class of intentional objects can open up new prospects and significantly expand the boundaries of the application of the activity approach in economic theory.

If, in accordance with the approach of modern economic theory, economic activity is considered primarily as an individual choice, then the alternative objects are precisely the intentional objects of such a choice. They form the very phenomenological objectivity, that "praxeological reality" with which modern economic theory begins to study. Such a phenomenological understanding of objectivity is actually inherent in modern economic theory in its neo-Austrian, and neoclassical, and neo-institutional versions.

Take, for example, the neo-institutional theory of property rights. Generally speaking, property rights, that is, the rights of individuals to use resources, are a historically defined social form of the individual's ability to choose his actions. A market transaction, that is, an exchange of property rights, is a specific social form of exchanging these opportunities. Property is considered in neo-institutional theory in the spirit

\footnotetext{
${ }^{1}$ Мизес, Л. (2001). Человеческая деятельность. Москва: Дело, 89.

2 Гуссерль, Э. (2001). Логические исследования. Москва: ДИК, 2, 175.
} 
of Anglo-Saxon law - as a bundle, a set of powers. In turn, each competency is a certain set of opportunities that open to its owner. Consequently, the exchange of property rights, powers - this is ultimately an exchange of opportunities. R. Coase emphasizes that "the market does not sell material items, as economists often assume, but the rights to carry out certain actions"1. Each competency expands the possibilities of the subject, his choice. So, A. Alchian defines the system of property rights as "the totality of methods for providing specific individuals with "authority" to choose any way of using specific goods from the class of prohibited methods of using these goods" .

Accordingly, commodity exchange is considered in neo-institutional theory not as an exchange of material objects, but as an exchange of property rights, that is, in other words, as an exchange of opportunities to act in a certain way with respect to these objects. Such an exchange of opportunities forms the content of market transactions, and the costs of this exchange of property rights form transaction costs.

However, there is not only an exchange of opportunities, but also the creative creation of fundamentally new opportunities. These creatively created features greatly complicate the definition of property rights. "For example, the introduction of new technical means, such as a car, photocopiers, computers, videotapes, often creates uncertainty about property rights, as a result of which rights of value remain in the public" property sector"3.

The decisive for the method of exchange is its intentional object, that is, what kind of alternative opportunities are exchanged. In this sense, the object of exchange determines the method of exchange ${ }^{4}$. Free, interpersonal exchange is adequate for personal, creatively created opportunities. Market transactions are adequate to social opportunities, but not to all, but only to those social opportunities that have exclusive, competitive use ${ }^{5}$. Their use by one subject excludes their use by another. However, in a specific historical form of property rights only a part of social opportunities appears while the other part is open for general use ${ }^{6}$.

The neo-institutional theory of property rights considers the exchange of goods as an exchange of property rights, i.e. as a market transaction 7.8 . A transaction is an exchange not of things, but of alternative possibilities, that is, intentional, and not material objects ${ }^{9}$. Here neo-institutionalism is in solidarity with neoclassicism, which, after the Austrian school, replaces the classical analysis of objective value with the analysis of opportunity costs. All these currents of modern economic thought are essentially based on the analysis of alternative opportunities that are objects of economic choice.

An understanding of activity as a choice is adequate for such a consideration of economic activity. In general, activity does not come down to choice. It is legitimate to consider economic activity as a choice from a certain set of alternative options for actions given to the subject from the outside. The economic entity does not create alternative opportunities for its actions. He receives them from the outside, from the society in a finished form. Therefore, he can only choose from the alternatives offered to him by society.

In contrast to economic activity and creativity is not limited to choice, it means a relatively independent creation by the subject himself of new alternative opportunities for his actions. The degree of this independence determines the measure of the creative content of the activity. It is this relative independence in creating new opportunities that elevates creativity over economic activities that use only those opportunities that society offers.

Generally speaking, a person's awareness of the alternative possibilities of his actions can occur in two ways. On the one hand, a person can learn about their existence from other people, from society, for example,

\footnotetext{
${ }^{1}$ Коуз, Р. Г. (2001). Нобелевская лекциия «Институцฺиональная структура производства», 1991. Природа фирмы. Москва: Дело, 48.

2 Эггертссон, Т. (2001). Экономическое поведение и институты. Москва: Дело, 130.

3 Эггертссон, Т. (2001). Экономическое поведение и институты. Москва: Дело, 53.

${ }^{4}$ Alchian, A. (1977). Economic Forces at Work. Indianapolis, 78.

${ }^{5}$ Royston, G., Oliver, C., Sahlin-Andersson, K., and Suddaby, R.(2008).The SAGE Handbook of Organizational Institutionalism. Thousand Oaks, CA: SAGE, 121.

${ }^{6}$ Royston, G., Oliver, C., Sahlin-Andersson, K., Suddaby, R. (2012). Institutional Theory in Organization Studies. London: SAGE, 87.

${ }^{7}$ Meyer, J. W., Richard Scott, W. (1983), Organizational Environments: Ritual and Rationality. Beverly Hills, CA: SAGE, 56.

${ }^{8}$ Meyer, J. W., Thomas, G., Ramirez, F., Boli, J. (1987). Institutional Structure: Constituting State, Society, and the Individual. Beverly Hills, CA: SAGE, 138.

${ }^{9}$ Powell, W W., DiMaggio, P. J. (1991). The New Institutionalism in Organizational Analysis. Chicago: University of Chicago Press, 98.
} 
during his upbringing, training, or through any other channels of movement and dissemination of knowledge between people such as market prices, media and communications, advertising, literature etc. In this case, the individual's awareness of the objectively existing possibility is mediated by society. In this sense, this alternative opportunity acts for the individual as a social opportunity provided to him by society.

But, on the other hand, the subject can not only get ready-made knowledge of opportunities from other people, but also create new opportunities, moreover, opportunities that are new not only for him, but also for other people, for society as a whole. Of course, without society and outside society, the creation of new alternative opportunities is extremely difficult. A creative subject isolated from objective knowledge would have to invent a bicycle at every step, and not only a bicycle, but even a wheel, which he would not find ready-made in primary, natural nature and could only be taken from society.

Creative activity involves not only choice, but also the creation of new alternative opportunities for him. If economic activity can be reduced only to the first element, then creativity necessarily involves the second. Both of these elements are associated with new alternative possibilities: one - with their creation, the other - with use. Therefore, the category of alternative opportunities is needed to describe not only purely economic activity as a choice, but also to analyze the elements of creativity "dissolved" in practical activity.

It was noted above that the division of labor and choice in capitalist production replaces their direct connection in the economic activity of the individual producer. At the same time, capitalist entrepreneurship opens up certain opportunities for enhancing the impact on material production from those spheres of spiritual production that were previously almost completely separated from it. This creates the conditions for unprecedented technological and economic development. Ultimately, this development reaches such a stage at which choice and action, entrepreneurship and work are complemented by the creative creation of new alternative options for action directly at the level of the corporation, acting in this case as a scientific and production complex. Moreover, under the influence of corporate connection, these elements begin to connect at the individual level. An individual action, acting as production in production, again begins to unite with choice, but now elements of creativity are joining it. Thus, in the historical trend, the denial of the classical capitalist division of economic activity into labor action and entrepreneurial choice begins. A partial return to their connection begins, but this connection now begins to be enriched also by elements of creativity that are practically alien to the former individual producer.

The modern innovative economy in this sense acts as the beginning negation of the capitalist separation of choice and action. But this does not mean a return to simple commodity production, but rather a peculiar historical synthesis of simple and capitalist commodity production. This historical synthesis takes from the simple commodity production a reunion of action and choice that begins on an individual level, and from capitalism - the addition to these stages of activity of those elements of creativity that were previously practically separated from material production and concentrated in the sphere of spiritual production, separated from material. The capitalist decomposition of economic activity into a choice and action, isolated and opposing each other in the form of a class contradiction, is only a historical condition for the subsequent complication of activity, a prerequisite for adding a creative element to these two elements of economic activity ${ }^{1},{ }^{2}$. The fourth technological revolution creates an adequate technological basis for these processes ${ }^{3},{ }^{4}$.

The world of objective knowledge forms the deepest, most universal basis for people to choose their individual actions. These individual opportunities can be of two types. First of all, they can serve as an expression of social need. Social necessity forms a transmission mechanism that mediates the connection of individual opportunities with objective knowledge as their universal basis. This transmission mechanism of social necessity itself is objectively necessary in order to fill the gap between individual actions and their universal basis.

Human actions become socially necessary precisely because of this, historically limited level of development of the objective basis of individual actions. The less historically developed this objective basis is, the more alienated it is from a person to take its form of manifestation, the more rigid and really uncontested is social need. Such a transformed form of his universal capabilities, alienated from the empirical individual, is the external social need for his individual actions.

\footnotetext{
${ }^{1}$ Scott, W. R. (2008). Institutions and Organizations: Ideas and Interests. London: SAGE.

${ }^{2}$ McAfee, A., Brynjolfsson, E. (2016). Human Work in the Robotic Future: Policy for the Age of Automation. Foreign Affairs, July/August, 23-28.

${ }^{3}$ Kenney, M., Zysman, J. (2016). The Rise of the Platform Economy. Issues in Science and Technology. 32 (3), 61-69.

${ }^{4}$ Gawer, A., Cusumano, M. A. (2012). Platform Leadership: How Intel, Microsoft, and Cisco drive industry

innovation. Boston: Harvard Business School Press.
} 
People are forced to perform certain actions, for example, to engage in routine, monotonous work, precisely because they still do not have objective opportunities to receive material benefits in another way. In this sense, socially necessary work supplements the objective possibilities for obtaining goods that are at a relatively low level of their historical development. With their socially necessary work, people are economically compelled to compensate for the insufficiently high level of development of the objective basis of their individual actions, namely, a level that is still insufficient to obtain material wealth in other ways.

Social necessity acts as historically undeveloped objective opportunities. Owing to this relative underdevelopment, the object basis of individual actions appears primarily in the form of social necessity, and not as the basis for the creative creation by people of new alternative opportunities for their actions. Thus, the less developed the objective basis of individual actions, the slower it develops. This dependence is empirically evident in the tendency to gradually accelerate the development of the objective basis of individual actions. When this objective basis reaches a certain level, their further development is sharply accelerated, which we observe directly and empirically clearly over the past centuries, starting at least from the 17 th-18th centuries.

Each given level of development of the objective basis of individual actions corresponds to a certain way of the relationship of objective knowledge with individual actions. At the same time, the following historical regularity looms quite distinctly. The higher the level of development of objective knowledge, the stronger the inverse, counter-dependence of this development on the individual actions of people carried out in a given period of time reveals itself. This means that the growth of objective knowledge tends to cumulative self-acceleration. The faster objective knowledge grows, and therefore, the higher the level of development it reaches, the stronger the trend becomes the reverse active influence of individual creativity on the level of objective knowledge. This creative impact increases the level of development of objective knowledge. Raising this level, in turn, stimulates individual creativity. This means a new inverse effect of individual actions on the level of objective knowledge. This interaction of subjective actions with their objective basis is reproduced each time at a new, higher level. This gives the development of objective knowledge the form of a self-accelerating process, the cumulative nature of which has been revealed especially clearly over the past centuries.

The very concept of a stationary level of development of objective possibilities is becoming more and more arbitrary. As objective knowledge grows, not only does the inverse effect of individual actions increase the development of objective knowledge, but the way the interaction of subjective actions with its objective basis gradually changes. Such interaction is becoming less and less connected with the transmission mechanism of objective possibilities as a form of manifestation of social necessity. These changes are associated with the creative creation of new alternative opportunities that, in a tendency, begin to gradually free themselves from social necessity.

In the knowledge society, the objective basis of individual actions acts as the starting point for the creative creation of new opportunities. In turn, new alternative opportunities are part of the objective basis for new individual actions. Such an expansion and complication of the universal foundation acts as a source of social necessity for those economic entities thatthey do not themselves create new alternative opportunities for their actions, but specialize in the routine use of ready-made objective opportunities. For such economic entities, this complication of objective knowledge quite naturally appears as a compulsory action of social necessity on them.

New opportunities here pass into a social need, imposed on the participants of the game by the compulsory force of competition. For each of them, the only way out of the game becomes submission to the extent that we are talking about economic entities that are not able to creatively create new alternative opportunities. Such a social need is realized, for example, through intra-industry competition, which forces lagging manufacturers to also introduce new equipment, technology and the organization of production after the leaders.

In a knowledge society, the period during which new alternative opportunities are truly new tends to be gradually reduced. And accordingly, the social necessity into which these new opportunities are moving is becoming ever more mobile, dynamic. Such dynamic social opportunities are less and less appealing as ready for routine, non-creative use. They act more like external impulses that stimulate their own creative activity of economic entities. The subject develops an internal ability not only to use ready-made opportunities, but also to create new opportunities for himself and thereby be drawn into the process of historical development of the objective basis of individual actions. The same historical pattern is manifested here: the higher is the level of development of objective knowledge as the objective basis of individual 
actions, the more directly this objective basis passes into creative self-development and self-determination. It acts as an objective basis for not just individual actions, but as a basis for the creative creation of new alternative opportunities.

Of course, social need is not yet disappearing, but it is becoming more flexible and dynamic. To an increasing extent, it no longer appears as a need to realize ready-made objective opportunities, but as a need to creatively create new alternative opportunities for its actions. Subjects incapable of this are forced to leave the game, since the mere use of ready-made objective opportunities to participate in this new game is no longer enough. Now it's not just routine actions that are becoming socially necessary, but to an increasing extent - the very elements of creative freedom. Thus, in the knowledge economy, socially necessary labor gradually begins to turn into individual freedom of creativity. Self-development of the objective framework is dramatically accelerated. As a result of this, the transition to a knowledge society appears as an era of cumulatively growing growth rates of objective knowledge.

Conclusions. The origins of the main trends of modern development lie in the very structure of modern individual choice, in the contradictory composition of those alternative opportunities on which this choice is based, in the tendency to change this composition - to increase the value of creative opportunities due to the relative decrease in the role of society-mediated opportunities. Of course, in any case, the initial, basic mass of opportunities is always taken from society in a ready-made form. The whole question is to what extent the subject adds to this set of opportunities mediated by society something of his own, personal, individual, or individual, is only the choice of these indirectly social opportunities. If he adds new opportunities created by himself that were previously unknown to society and at the same time socially significant, that is, relevant for other subjects as possible options for their choice, then these new opportunities act as creative and personal ones.

Just as the primitive man did not wait until the primary, natural nature satisfied his needs, and began to create something objective for their satisfaction, so does the modern man living in a highly developed society, no matter how average, mass-impersonal he is, I'm no longer inclined to choose only from that set of indirectly social opportunities that society offers him. It is already on a larger scale, more and more massively begins to create new opportunities for itself with its own creativity, so that it gradually becomes the norm in the life of a highly developed society, penetrating even the most secret "bowels of production" that were traditionally the patrimony of boring, stupid person labor. Elements of creativity become a social norm, not only for the intellectual elite, but also for a wide range of ordinary representatives of the numerous "creativewow class".

Thus, we come to the conclusion that the synthesis of the concept of alternative choice with a political and economic approach to the analysis of creative activity is methodologically quite possible. This leads to the conclusion that, thanks to this synthesis, the methodological foundations of the analysis of creative activity in economic theory acquire a dual character. On the one hand, such an analysis proceeds from alternative possibilities of individual choice, which corresponds to the methodology of modern neoclassical theory. This methodological basis of the analysis of creative activity allows us to establish a methodological connection between neoclassical microeconomics and political economy, which contributes to the integration of economic theory as a single scientific discipline.

Another methodological basis for the analysis of creative activity is the inherent political economy historical approach to research. Such an approach allows us to consider the "creative class" in the broad historical context of the process of transforming the content of human activity in the direction of development of creative elements in it that begins in highly developed countries. The general methodological conclusion is that these elements of creativity should be considered from the point of view of the historical dynamics of modern society, taking into account both the modern stage of its evolution and the prospects for the further development of the process of creative transformation of the content of human activity. In the future, such a dynamic approach to the analysis of creative activity is capable of laying the methodological foundations for further research on the creative transformation of human activity, opening up great opportunities for the development of economic theory as a unified science along the path of integrating the achievements of political economy and microeconomics.

\section{References:}

1. Florida, R. (2002). The Rise of the Creative Class. And How It's transforming Work, Leisure, Community and Everyday Life. New York: Basic Books. [in English].

2. Florida, R., Tinagli, I. (2004) Europe in the Creative Age. Pittsburgh: Carnegie Mellon Software Industry Center. London: Demos. 12-35. [in English]. 
3. Florida, R. (2004). Creative Class War. Washington: Monthly, 7-18. [in English].

4. Lendri, Ch. (2006). Kreativnyj gorod [Creative city]. Moscow: Klassika XXI. [in Russian].

5. Hokins, Dzh. (2006). Kreativnaya ekonomika [Creative economy]. Moscow: Klassika XXI. [in Russian].

6. Inozemcev, V. L. (1998). Za predelami ekonomicheskogo obshestva [Beyond the economic society]. Moscow: Nauka. [in Russian].

7. Buzgalin, A. V., Kolganov, A. I. (2019). Predely kapitala: metodologiya i ontologiya [The Limits of Capital: Methodology and Ontology]. Moscow: Kulturnaya revolyuciya. [in Russian].

8. Buzgalin, A. V., Kolganov, A. I. (2017). Globalnyj kapital [Global capital]. Moscow: Alternativy, 2. [in Russian].

9. Gricenko, A. A. (2018). Razvitie form obmena, stoimosti i deneg [The development of forms of exchange, value and money]. Kyiv: Osnova. [in Russian].

10. Gricenko, A. A. (2018). Sovmestno-razdyolennyj trud kak ishodnaya kategoriya politicheskoj ekonomii i eyo predmet [Jointly-divided labor as an initial category of political economy and its subject]. Voprosy politicheskoj ekonomii [Questions of Political Economy], 3 (18), 5-11. [in Russian].

11. Mezhuev, V. M. (2017). Marks protiv marksizma [Marx against Marxism]. Moscow: Logos. [in Russian].

12. Pusenkova, I. V. (2001). Metodologiya analiza razvitiya ot ekonomiki $k$ intellektu [Methodology for the analysis of development from economics to intelligence]. Odessa: Astroprint. [in Russian].

13. Gorc, A. (2018). Nematerialnoe: znanie, stoimost i kapital. K kritike ekonomiki znanij [Intangible: knowledge, value and capital. Toward a Critique of the Knowledge Economy]. Moscow: GU-VShE. [in Russian].

14. Mizes, L. (2001). Chelovecheskaya deyatelnost [Human activity]. Moscow: Delo. [in Russian].

15. Gusserl, E. (2001). Logicheskie issledovaniya [Logical research]. Moscow: DIK, 2. [in Russian].

16. Kouz, R. G. (2001). Nobelevskaya lekciya Institucionalnaya struktura proizvodstva, 1991. Priroda firmy [Nobel lecture Institutional structure of production. Company nature]. Moscow: Delo. [in Russian].

17. Eggertsson, T. (2001). Ekonomicheskoe povedenie i instituty [Economic Behavior and Institutions]. Moscow: Delo. [in Russian].

18. Alchian, A. (1977). Economic Forces at Work. Indianapolis. [in English].

19. Royston, G., Oliver, C., Sahlin-Andersson, K., Suddaby, R.(2008). The SAGE Handbook of Organizational Institutionalism. Thousand Oaks, CA: SAGE. [in English].

20. Royston, G., Oliver, C., Sahlin-Andersson, K., Suddaby, R. (2012). Institutional Theory in Organization Studies. London: SAGE. [in English].

21. Meyer, J. W., Richard, S. W. (1983). Organizational Environments: Ritual and Rationality. Beverly Hills, CA: SAGE. [in English].

22. Meyer, J. W., Thomas, G., Ramirez, F., Boli, J. (1987). Institutional Structure: Constituting State, Society, and the Individual. Beverly Hills, CA: SAGE. [in English].

23. Powell, W., DiMaggio, P. J. (1991). The New Institutionalism in Organizational Analysis. Chicago: University of Chicago Press. [in English].

24. Scott, W. R. (2008). Institutions and Organizations: Ideas and Interests. London: SAGE. [in English].

25. McAfee, A., Brynjolfsson, E. (2016). Human Work in the Robotic Future: Policy for the Age of Automation. Foreign Affairs. [in English].

26. Kenney, M., Zysman, J. (2016). The Rise of the Platform Economy. Issues in Science and Technology, 32 (3), 61-69. [in English].

27. Gawer, A., Cusumano, M. A. (2012). Platform Leadership: How Intel, Microsoft, and Cisco drive industry innovation. Boston: Harvard Business School Press. [in English]. 